\title{
CONFLICTS OF JURISDICTION UNDER THE NEW RESTATEMENT
}

\author{
KARL M. MEeSSEN*
}

\section{A View from Outside the United States}

The Restatement of the Law, Foreign Relations Law of the United States (Revised), ${ }^{1}$ as the new Restatement's official title runs, was finally adopted by a unanimous vote of the members of the American Law Institute on May 14, 1986.2 The Restatement is now expected to be published during the first months of 1988. Its earlier tentative drafts already have made their way into court opinions and diplomatic correspondence, ${ }^{3}$ and the final text is sure to have, for years to come, an impact on judicial and diplomatic practice, inside and outside the United States, not easily matched by any other pronouncement short of binding authority.

A restatement seeks to state the law already in existence. It should not be mistaken for a formal source of law. The persuasiveness of a restatement therefore depends on the amount of consensus it reflects. There may well be a difference between the situation inside and outside the United States with respect to restating foreign relations law: Those portions which, as section 1(b) of the Restatement (Revised) puts it, state "domestic law that has substantial significance for the foreign relations of the United States or has

Copyright (C) 1988 by Law and Contemporary Problems

* Professor of Public Law, International Law, European Law, and International Economic Law at the University of Augsburg, Augsburg, Federal Republic of Germany; Professor of International Trade Law at the Graduate Institute of International Studies, Geneva, Switzerland.

The author was "Special Consultant on International Economic Law" within the "International Advisory Panel" set up by the American Law Institute with respect to the Restatement (Revised), Foreign Relations Law of the United States. He now is "Rapporteur" of the "Committee on Extraterritorial Jurisdiction" recently established by the International Law Association.

1. Restatement (Revised) of Foreign Relations law of the United States (Tent. Final Draft, Apr. I, 1986) (unpublished) [hereinafter Restatement (Revised)]. A small number of copies of that text, which was finally adopted during the 1986 Annual Meeting of the American Law Institute, were on display at that meeting. The literal quotations and numbering of sections in this paper are taken from the version now in the process of printing. Whenever a section whose number has changed is mentioned in the footnotes of this paper for the first time, the numbering of earlier drafts will be indicated in parentheses.

2. See 63 A.L.I. Proc. 140-42 (1987).

3. For court decisions, see the Cumulative Annual Pocket Part of the Restatement (Second) of Foreign Relations Law of the United States (1965) [hereinafter Restatement (Second)]. For an example of diplomatic practice, see Comments on the U.S. Regulations Concerning Trade with the U.S.S.R., 21 Int'l Legal Materials 891, 900-01 (1982) [hereinafter Comments] (Presented to the Department of State by a note of the Delegation of the Commission of the European Communities in Washington, D.C., on Aug. 12, 1982. The full text was published in the article, Europe Protests Reagan Sanctions on Pipeline Sales, N.Y. Times, Aug. 13, 1982, § A, at 1, col. 2.). 
other substantial international consequences" mainly require acceptance within the United States whose legal community was well represented by the American Law Institute's elected membership of about 2000 distinguished lawyers. Those portions, however, that according to section 1(a) state "international law as it applies to the United States" will have to be carried by a consensus at both ends of any given rule of international law, at the United States' end and at the foreign States' end. Acceptance of the international law rules would therefore have to be derived from lawyers outside the United States as well or, in the last analysis, from all the peoples of the world.

Foreign governments, speaking on behalf of their respective peoples, will be quick to utilize the Restatement for their own purposes. Objections against undesirable conduct of the United States Government are likely to be presented, as they were already, by reference to the standards of the Restatement. ${ }^{4}$ It is more difficult to predict which attitude foreign governments will adopt once they are themselves reproached for deviating from rules laid down in the Restatement. The Restatement's provisions relating to international law proper could then be subjected to careful scrutiny on whether they indeed reflect customary international law as understood both inside and outside the United States.

The American Law Institute was conscious of the additional problems involved in restating international law. In 1982, upon drafting three-fifths of the entire subject matter, a panel of six international advisers was composed. ${ }^{5}$ This writer was privileged to have been one of them, with a special mandate for international economic law. He may, at this occasion, be permitted to put on record his appreciation of the openness with which his observations and comments were received and discussed both at the annual meetings of the Institute and at the informal gatherings of the American advisers to which he had kindly been invited.

The efforts at building consensus on the rules of international law stated in the new Restatement, however, will have to be continued on a broader basis once the Restatement is published. The purpose of this paper is to contribute to that venture by offering a view from outside the United States on those issues that were among the most controversial in the preparation of the new Restatement, to wit the Restatement's provisions on conflicts of jurisdiction. The presentation will first turn to the breakdown of the subject matter of state jurisdiction (section II below) and then proceed to discuss the structure of the pertinent rules of international law (section III below). The final section will be devoted to an attempt to explain the differences in balancing state interests with respect to true and false conflicts of jurisdiction (section IV below).

4. See, e.g., Comments, supra note 3 .

5. The names were listed for the first time on the introductory pages of RESTATEMENT (Revised) of Foreign Relations law of the United States (Tent. Draft No. 4, 1983). 


\section{Breakdown of Subject Matter}

To divide the subject matter into several dozen sections on jurisdiction, the Restatement (Revised) mainly makes use of two criteria. One distinction is according to the different state functions of prescriptive, adjudicative, and enforcement jurisdiction (subsection A below), and the other one is according to the various fields of law, such as criminal law, antitrust law, etc. (subsection B below).

\section{A. The Different State Functions}

The preceding restatement, the Restatement (Second) of Foreign Relations Law of 1965, distinguished between prescriptive jurisdiction and enforcement jurisdiction. ${ }^{6}$ The reporters for the Restatement (Revised) advocated that these categories be supplemented by adding adjudicative jurisdiction as a third category. That proposal drew a large number of comments from members of the Institute. Yet, reading the verbatim record of the debate at the annual meetings of 1981 and 1982, one finds oneself confronted with a considerable lack of enthusiasm for the distinctions made. And there was indeed, as one of the reporters put it, "confusion in the hall."7 But alternative proposals found no support either. The categories were slightly modified by the reporters and in that form withstood later informal questioning as well. Section 401 now reads:

Under international law, a state is subject to limitations on

(1) jurisdiction to prescribe, i.e., to make its law applicable to the activities, relations, or status of persons, or the interests of persons in things, whether by legislation, by executive act or order, by administrative rule or regulation, or by determination of a court;

(2) jurisdiction to adjudicate, i.e., to subject persons or things to the process of its courts or administrative tribunals, whether in civil or in criminal proceedings, whether or not the state is a party to the proceedings;

(3) jurisdiction to enforce, i.e., to induce or compel compliance or punish noncompliance with its laws or regulations, whether through the courts or by use of executive, administrative, police, or other nonjudicial action. ${ }^{8}$

The number of provisions grouped in each of the various chapters and subchapters on prescriptive, adjudicative, and enforcement jurisdiction is not too impressive.9 The subchapter on "Immunity of Foreign States from

6. Restatement (Second), supra note $3, \S \S 6,7$.

7. See 58 A.L.I. Proc. 220-47 (1982); 59 A.L.I. Proc. 120-38 (1983); 62 A.L.I. Proc. 403 (1986).

8. Restatement (Revised), supra note $1, \S 401$.

9. Id. (Chapter 1 "Jurisdiction to Prescribe," Subchapter A "Principles of Jurisdiction to Prescribe": $\$ \S 402-404$, Subchapter B "Principles of Jurisdiction Applied": $\$ \$ 411-413,414$ (§ 418), Subchapter C "Principles of Jurisdiction: United States Applications": $\$ \S 415-416$. Chapter 2 "Jurisdiction to Adjudicate": $\$ \S 421.423$ (\$\$ 441-443). Chapter 3 "Jurisdiction to Enforce": \$\$ 431-433. Chapter 5 "Immunity from Jurisdiction of States," Subchapter A "Immunity of Foreign States from Jurisdiction to Adjudicate": $\$ \S 451-460$, Subchapter B "Immunity of Foreign States from Jurisdiction to Prescribe": $\$ \S 461-462$ ( $\S \S 441-442$ ), Subchapter C "Immunity of Foreign States from Jurisdiction to Enforce": $\S 463$ ( $\$ 461)$.). 
Jurisdiction to Enforce," which consists of only one provision and contains no references to actual cases, even seems somewhat artificial. Important provisions, such as those on "Foreign Government Compulsion" and on "Requests for Disclosure," stay outside the three categories, ${ }^{10}$ and the rules regarding adjudicative and enforcement jurisdiction do not look very different from the corresponding rules on prescriptive jurisdiction since most of them refer back to reasonableness as a main criterion for legal exercise of jurisdiction."

The limited use the Restatement makes of its own distinction, despite contrary intentions of its authors, reflects a legal truism. Adjudication and enforcement are subordinate to those acts of legislation to which they are related. If international law does not permit legislative acts to cover certain types of foreign conduct, the respective state is charged with avoiding a violation of international law, if possible already at the stage of legislation, by limiting the scope of application of domestic law or by inserting in the statute a reference to international law. In case, as often happens, an infringement of international law is not entirely excluded by the formulation of the legislative or, to cover administrative regulations as well, prescriptive act, conformity with international law will have to be brought about at the stage of adjudication or enforcement lest the respective state be held liable for a reparation of injuries under the international law rules of state responsibility. The international law rule infringed upon, however, would always be the one on prescriptive jurisdiction.

State jurisdiction is about regulating conduct by law and therefore always a matter of prescriptive jurisdiction. To form categories of adjudicative and enforcement jurisdiction seems unwarranted. It could, however, be considered whether, within prescriptive jurisdiction, separate categories of prescriptive jurisdiction regarding adjudication and enforcement could be split off, confining the residual category of prescriptive jurisdiction proper to the stage of legislation, as was probably the Institute's intention. Admittedly, the jurisdictional issues which arise at the stage of adjudication and enforcement are different from those at the stage of legislation. The difference is one of greater complexity. In analyzing acts of legislation, the focus is put on one rule after the other. Yet adjudication and enforcement necessarily relate to a number of legal rules at the same time. Each of those rules might raise an issue of jurisdiction of its own. In the following paragraphs, jurisdictional problems typically presenting themselves at those stages will be discussed to find out whether the respective conclusions could, for practical reasons, usefully be summarized to constitute distinct categories of prescriptive jurisdiction regarding adjudication and enforcement.

10. Id. (Chapter 4 "Jurisdiction and the Law of Other States," Subchapter A "Foreign State Compulsion" (corresponding to Chapter 4 "Conflicts of Jurisdiction" in the adopted text): $\$ \S 441$ 442 (originally $\S \S 419-420$, then $\$ \S 436-437$ ).).

11. Id. $\$ \S 421,423,431,432$. 
The exercise of "personal jurisdiction" over the defendant (in the meaning of that term under U.S. law) might be questionable even though the conduct, a securities transaction for instance, is undisputably subject to domestic substantive law ("subject matter jurisdiction" in the terminology of U.S. law). In that case, prescriptive jurisdiction as to substantive law is present whereas prescriptive jurisdiction as to the procedural law providing for personal jurisdiction is lacking. As a result, domestic substantive law might turn out to be unenforceable unless, as is often the case, an alternative way of enforcement, for example, by proceeding against the domestic seller of the securities, is available.

The procedural law on taking evidence abroad is another matter as to which prescriptive jurisdiction may be lacking, even when prescriptive jurisdiction regarding the laws applicable to the merits of, for instance, a product liability claim and also regarding the laws on personal jurisdiction is present. Again, adjudication and enforcement would depend on the availability of alternative ways to produce the necessary evidence, either by exclusively relying on evidence located in domestic territory or by gaining access to evidence abroad through the assistance of the foreign territorial sovereign.

The reverse situation is conceivable as well. Prescriptive jurisdiction regarding substantive law, in the field of antitrust for instance, may be in doubt. Yet, at the same time the defendant may be presumed to be subject to suit in domestic courts with the necessary evidence also available in domestic territory. Thus, prescriptive jurisdiction regarding the rules of domestic procedural law, both on personal jurisdiction and on taking evidence, would be present. In that case, domestic adjudication and enforcement could only be undertaken if designed to implement the law of the respective foreign state that has antitrust jurisdiction.

The category of prescriptive jurisdiction regarding adjudication-the same applies to enforcement-fails to adequately reflect the various constellations of jurisdictional problems likely to arise at the stage of adjudication and enforcement. To establish separate rules of jurisdiction dealing with adjudication and enforcement as a whole is at odds with the requirements of practice and even liable to produce inaccurate results. However, instead of forming two separate categories of prescriptive jurisdiction to cover all the problems of adjudication and enforcement, a greater number of categories of prescriptive jurisdiction in the procedural law on personal jurisdiction, on taking evidence abroad, and so on, and in the law on the different aspects of non-judicial enforcement could and, indeed, should be formed. Such categories would not rank with priority to, but constitute an integral part of, the distinction according to the various fields of law. This distinction will be discussed in the following subsection.

There is no mysterious additional dimension of jurisdictional problems inherent in adjudication and enforcement: At those stages as well, the jurisdictional problems regarding each applicable rule of substantive law and 
of the law of judicial and administrative procedure have to be examined; the various conclusions reached by such discriminate analysis of each jurisdictional problem can, with precision, be summarized only for the purposes of a particular case or a clearly defined group of cases.

\section{B. The Various Fields of Law}

A breakdown of the subject matter according to the various fields of law seems less imaginative but also more persuasive than the categorization discussed before. It is indeed by investigating the particular constellation of regulatory interests that more specific rules will have to be formulated both $d e$ lege lata and de lege ferenda.

The American Law Institute singled out criminal law for a statement of different rules of prescriptive, adjudicative, and enforcement jurisdiction. ${ }^{12}$ Tax law is also attributed separate provisions of prescriptive jurisdiction. ${ }^{13}$ Another rule of prescriptive jurisdiction covers "Jurisdiction with Respect to Activities of Foreign Branches and Subsidiaries." ${ }^{14}$ That rule, however, is less specific than it may seem on first sight. It relates, as the examples given in the reporters' notes demonstrate, to all those regulatory laws which refer to corporate links between parent and subsidiary, for example, corrupt practices law, export control law, and banking supervision law. ${ }^{15}$ The focus, therefore, is on the principle of active personality as a connecting factor rather than on a particular field of law. Particular fields of law again serve as categories for several rules stated only for the purposes of U.S. law, such as two additional rules on criminal law ${ }^{16}$ and the only rule on antitrust law and security exchange law respectively. ${ }^{17}$

The Restatement's efforts to distinguish between the various fields of law should have been pursued further. In embargo law, for instance, as will be explained in section III. A. below, the peculiarities of connecting factors could be established in a more precise manner. ${ }^{18}$ As to procedural law, some steps in the right direction have already been taken by formulating rules on the service of documents and discovery which, nota bene, stay outside the Restatement's categories of prescriptive, adjudicative, and enforcement jurisdiction. ${ }^{19}$ Regarding both the rules stated already and the rules to be stated in the future, a broader coverage of material outside the United States seems desirable.

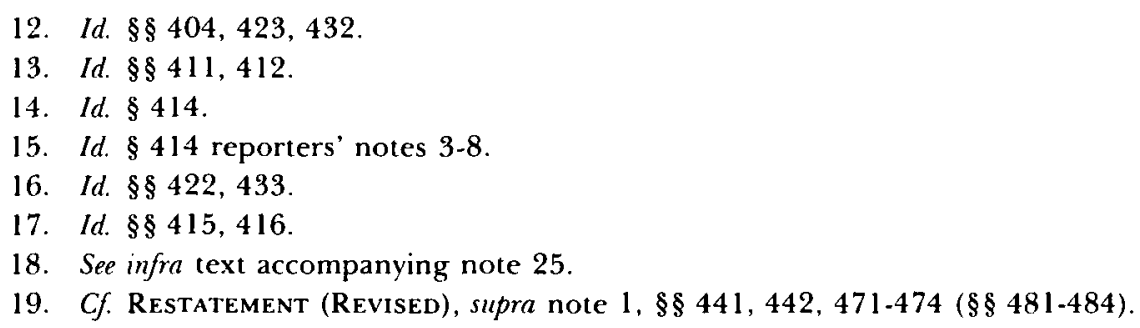




\section{III}

\section{Structuring the Rules}

For a restatement to be meaningful, its rules have to be as close as possible to that invisible line which separates the lex lata from the lex ferenda. Whether or not that line was occasionally overstepped is an important question to be raised when the rules are applied to particular cases. But today's lex ferenda might be tomorrow's lex lata if only due to the impact of the Restatement itself. This paper therefore focuses on the structure of the rules, with a particular emphasis on their attribution to international law or national law since, in the latter case, they would still be, even if part of the lex lata, at the disposal of the legislator. The following discussion will be limited to the Restatement's three principal rules: on connecting factors (subsection A below), on reasonableness (subsection $B$ below), and on balancing of state interests (subsection $\mathrm{C}$ below).

\section{A. The Connecting Factors Approach}

National law rules of conflict of laws usually provide for a choice of the applicable law under criteria which relate characteristic elements of the facts to a particular state. Rules based on connecting factors, such as domicile, place of performance, etc., can be fairly precise. Hence, ever since the Lotus case $^{20}$ established jurisdiction as a problem of international law, efforts are under way to formulate rules of international law defining outer limits to state jurisdiction by permitting reference to some connecting factors and outlawing reference to others. In that 1927 decision, the captain of the French vessel Lotus was considered responsible for a collision on the high seas with the Turkish vessel Boz-Kourt, causing the death of a number of Turkish sailors. The issue was whether the occurrence of negligent manslaughter on a Turkish vessel would suffice to establish the criminal jurisdiction of Turkey. ${ }^{21}$ When, in the wake of the Alcoa case, ${ }^{22}$ the Lotus principle of objective territoriality suddenly found itself at the center of a debate on the limits of antitrust jurisdiction, the largely uncontroversial connecting factors of criminal law were assumed to become controlling in other fields of law as well. ${ }^{23}$ Section 402 of the Restatement (Revised) is in line with that approach when it describes and slightly generalizes traditional connecting factors. Section 402 reads:

Subject to $\S 403$, a state has jurisdiction to prescribe law with respect to

(1) (a) conduct that, wholly or in substantial part, takes place within its territory;

(b) the status of persons, or interests in things, present within its territory;

20. France v. Turkey, 1927 P.C.I.J. (Ser. A) No. 10 (the S.S. Lotus case).

21. The question was, on the casting vote of the president of the court, answered in the affirmative. See id. at 32.

22. United States v. Aluminum Co. of Am., 148 F.2d 416 (2d Cir. 1945).

23. See, e.g., Haight, International Law and Extratervitorial Application of the Antitust Lau's, 63 YALE L.J. 639 (1954); $c f$. Jennings, Extraterritorial Jurisdiction and the L'nited States Antitrust Lawes, 33 BRIT. Y.B. INT'L L. 146 (1957). 
(c) conduct outside its territory that has or is intended to have substantial effect within its territory;

(2) the activities, interests, status, or relations of its nationals outside as well as within its territory; and

(3) certain conduct outside its territory by persons not its nationals that is directed against the security of the state or a limited class of other state interests. ${ }^{24}$

One may wonder why the Institute attempted to cover all fields of law by a single set of principles embodying connecting factors. There is still some chance that, in a particular field of law, certain connecting factors constitute elements of a more specific rule of customary international law, especially when deviating from such factors as have regularly met with the opposition of foreign governments and were for that reason subsequently avoided. Whether more particularized connecting factors would lend themselves to description in terms of status of persons and place of conduct is an open question. Examining export control law, for instance, it is the origin of a product itself that explains why a state might be entitled to exclude certain foreign states as places of ultimate destination. No government can be expected to remain inactive when, to give an example, domestic planes are downed by missiles of domestic production that somehow made their way into the hands of terrorists supported by this or that foreign state. ${ }^{25}$ It therefore seems worthwhile to elaborate rules that directly address that particular connecting factor rather than to look for a justification under the principle of objective territoriality or any other principle of criminal law reflected in section 402. Of course more specific rules would also have to provide for the necessary limitations under parameters, such as the military nature of the product, the time element in adopting regulations regarding state of ultimate destination, and other factors protecting legitimate interests of states involved in re-exporting the products in question.

Section 402 is of limited significance. In terms of a general rule, its formulation could not have been substantially more precise. Yet too little effort was made in developing specific rules. Those on antitrust law and on securities transactions seek to state U.S. law and, only indirectly, state propositions regarding international law whose contents, however, are questionable especially because they fail to take sufficient note of foreign practice. The rules on criminal law and tax law remain somewhat short of the really controversial issues. Apparently all hopes were directed to the principle of reasonableness whose protective potential is to be explored in the following section.

\section{B. Reasonableness or the Renvoi to the Enlightened Self-Interest}

1. Reasonableness Under the Restatement. Reasonableness as a principle of the international law of jurisdiction has many roots. The most obvious one certainly is section 40 of the Restatement (Second) of 1965 which reads:

24. Restatement (Revised), supra note $1, \S 402$.

25. For a discussion, sec Meessen, Extraterritoriality of Expont Control: A German Lau'ver's thalysis of the Pipeline Case, 27 Ger. Y.B. INT'L L. 97 (1984). 
Where two states have jurisdiction to prescribe and enforce rules of law and the rules they may prescribe require inconsistent conduct upon the part of a person, each state is required by international law to consider, in good faith, moderating the exercise of its enforcement jurisdiction, in the light of such factors as

(a) vital national interests of each of the states,

(b) the extent and the nature of the hardship that inconsistent enforcement actions would impose upon the person,

(c) the extent to which the required conduct is to take place in the territory of the other state,

(d) the nationality of the person, and

(e) the extent to which enforcement by action of either state can reasonably be expected to achieve compliance with the rule prescribed by that state. ${ }^{26}$

In the Restatement (Revised), the binding character of the operative rule was upgraded from "required by international law to consider, in good faith, moderating the exercise" to a straightforward "may not exercise." But the requirements for the application of the rule remain as open-ended as ever. The list of factors to be considered, which continues to be non-exhaustive, was extended beyond the one of section 40 and even beyond the more lengthy ones contained in the Timberlane opinion of $1976^{27}$ and in the Mannington Mills opinion of $1979 .{ }^{28}$ Another change was to state the principle primarily as one of prescriptive jurisdiction rather than enforcement jurisdiction which, however, makes no difference in substance. ${ }^{29}$ Subsections (1) and (2) of section 403 (subsection (3) will be discussed in subsection III of this paper) read:

(1) Even when one of the bases for jurisdiction under $\$ 402$ is present, a state may not exercise jurisdiction to prescribe law with respect to a person or activity having connections with another state when the exercise of such jurisdiction is unreasonable.

(2) Whether the exercise of jurisdiction over a person or activity is unreasonable is determined by evaluating all relevant factors, including, where appropriate:

(a) the link of the activity to the territory of the regulating state, i.e., the extent to which the activity takes place within the territory, or has substantial, direct, and foreseeable effect upon or in the territory;

(b) the connections, such as nationality, residence, or economic activity, between the regulating state and the persons principally responsible for the activity to be regulated, or between that state and those whom the regulation is designed to protect;

(c) the character of the activity to be regulated, the importance of regulation to the regulating state, the extent to which other states regulate such activities, and the degree to which the desirability of such regulation is generally accepted;

(d) the existence of justified expectations that might be protected or hurt by the regulation;

(e) the importance of the regulation to the international political, legal or economic system;

(f) the extent to which the regulation is consistent with the traditions of the international system;

(g) the extent to which another state may have an interest in regulating the activity; and

26. Restatement (Second), supra note $3, \S 40$.

27. Timberlane Lumber Co. v. Bank of Am., 549 F.2d 597, 613-15 (9th Cir. 1976), cert. denied. 472 U.S. 1032 (1985).

28. Mannington Mills, Inc. v. Congoleum Corp., 595 F.2d 1287, 1297-98 (3d Cir. 1979).

29. See supra Section II, Subsection A. 
(h) the likelihood of conflict with regulation by another state. ${ }^{30}$

Reasonableness, also in a legal context, is not a new term but an attractive one. Who would like to be known as objecting to reasonableness? The term has an especially positive ring to antitrust lawyers, who, in ascertaining the effects of business practices on competition, have become accustomed to applying the rule of reason. ${ }^{31}$ In fact, it was with respect to extraterritorial antitrust jurisdiction that Kingman Brewster, in 1958, first relied on that rule in developing a multifaceted spectrum of considerations for jurisdictional restraint. ${ }^{32}$ Andreas Lowenfeld, the Associate Reporter in charge of the sections on jurisdiction, made that principle the cornerstone of his views on jurisdiction in his Hague Lectures of $1979^{33}$ and later in the Restatement itself. ${ }^{34}$

2. Reasonableness Under United States Conficts Laws. Reasonableness "is established in U.S. law, and has emerged as a principle of international law as well." 35 To judge the second part of that proposition contained in the comments to section 403 , one will have to look into its first part and examine the role of reasonableness in U.S. conflicts law. There, reasonableness is a twin of comity. At least, it shares with comity all its potentials and its limitations.

Like reasonableness, comity calls for restraint in the application of domestic law in view of legislative, executive, and judicial acts of a foreign State. ${ }^{36}$ The list of factors to be considered is open-ended as well. In fact, Timberlane ${ }^{37}$ and Mannington Mills ${ }^{38}$ were just as much an application of section 40 of the Restatement (Second) (the predecessor rule to reasonableness) as they were the product of a long line of precedents dating even further back than the Supreme Court decision in Hilton v. Guyot. ${ }^{39}$ The open-ended character of the rules implies that both reasonableness and comity are subject to guidance by domestic legislative intent, which may shift appreciation of factors to be considered in such a way as to disregard countervailing interests of foreign States in view of domestic regulatory goals of overriding importance. ${ }^{40}$ The meaning of reasonableness, therefore, is ultimately determined by the political branches of government, just as it is inherent in

30. Restatement (REvised), supra note 1 , § 403.

31. L. Sullivan, Handbook of the Law of Antitrust 165 (1977).

32. K. Brewster, Antitrust and American Business Abroad 53-98, 442-58 (1958).

33. Lowenfeld, Public Law in the International Arena, 163 ReCeuil des Cours 31 1, 326 (1979) (using the term "appropriateness").

34. See the Introductory Note to Subchapter A of Chapter 1 of Part IV \& Comments and Reporters' Notes to $\$ 403$ in the Restatement (Revised), supra note 1.

35. Id. $\S 403$ comment a.

36. For a recent confirmation of the principle, see Societe Nationale Industrielle Aerospatiale v, United States Dist. Ct., 107 S. Ct. 2542, 2555 (1987). For a short summary, see infra text accompanying notes $43-46$.

37. See supra note 27.

38. See supra note 28 .

39. 159 U.S. 113 (1895).

40. See Restatement (Revised), supra note 1 , comment c (at the end), $g$ (at the beginning). But see id. $\$ 403$ comment $g$ (at the end). 
comity to defer to the views of the political branches for an evaluation of domestic and foreign interests. ${ }^{41}$

Comity and reasonableness develop their role of accommodating foreign state interests only within the confines of domestic legislation and case law. Law-applying agencies are to look beyond the immediate objectives of a particular regulatory law. Foreign state interests are to be taken into account and deferred to as long as domestic policy goals can still adequately be reached in some other way. Comity and reasonableness, also for considerations of reciprocity, suggest refraining from taking measures not really necessary to reach the policy goal chosen. They call for rigorous rationality and thereby serve the enlightened self-interest of the domestic state. ${ }^{42}$

The recent Aerospatiale decision of the U.S. Supreme Court, ${ }^{43}$ characteristically referring both to comity and to the Restatement's provision embodying reasonableness, may serve to illustrate the point. In that case, the Federal Rules of Civil Procedure were clearly applicable and permitted ordering the production of documents located in France. But, in view of French objections to such long-arm discovery, a majority of five Justices of the Supreme Court held that a particularized analysis of the respective interests must be undertaken and may require that the evidence be taken in a manner less intrusive into foreign sovereignty, by filing a request for foreign legal assistance under the Hague Evidence Convention of 1970,44 provided that certain requirements of practicability and effectiveness are met. ${ }^{45}$ The four dissenting Justices derived from a generalized comity analysis that recourse to Convention procedures must be taken as a first resort whenever documents subject to discovery are located abroad. ${ }^{46}$

3. Reasonableness Under Conflicts Law Outside the United States. The principle of reasonableness is indeed a well-established rule of U.S. law regarding conflicts of jurisdiction. Is it a rule of the conflicts law of other states as well? An answer cannot be given here because it would presuppose looking into every system of national law. Should reasonableness, supposing it is not yet a rule of the law of a particular foreign state, be recommended for incorporation into the law of that state? This question raises complex issues of legal policy that again cannot be discussed without reference to the respective legal system. Two general points may, however, be made:

(1) Reasonableness as such, i.e., understood as a reference to a non-exhaustive list of a variety of factors to be considered, may in some legal systems be deemed to give too

41. See, e.g., Laker Airways Lid. v. Sabena, Belgium World Airlines, 731 F.2d 909, 948-56 (D.C. Cir. 1984).

42. For a discussion of the term "enlightened self-interest," see Meessen, Antitrust Jurisdiction Under Customany International Law, 78 AM. J. INT'L L. 783, 800-01 (1984).

43. See supra note 36.

44. Convention on the Taking of Evidence Abroad in Civil or Commercial Matters, Mar. 18, 1970, 23 U.S.T. 2555 , T.I.A.S. No. 7444,847 U.N.T.S. 231.

45. Id. at 2555-57.

46. Id. at 2561 . 
broad an authority to the judicial branch. ${ }^{47} \mathrm{~A}$ limitation of that authority may be required for the power of the judiciary to remain, in the words of Montesquieu, "en quelque facon nulle." 48 The limitations traditionally respected in the United States case law on comity take care of that problem. But those limitations cannot be reproduced by a single act of legislation in another state that does not have that tradition.

(2) A number of legal rules in other legal systems could at least partially fulfill functions assigned to comity in United States law. In German law, for instance, measures of regulatory law are open to challenge under the constitutional law principle of proportionality calling for a close scrutiny of the necessity to impose limitations upon the freedom of citizens in view of the respective regulatory goal to be reached. ${ }^{49}$

The overall object of reasonableness of adjusting domestic regulation to international conditions is certainly shared by other states, although the need for a flexible device of restraint, as it is felt in the United States, may not be present everywhere.

4. Reasonableness Under Intermational Law. Reasonableness is a principle of conflict of laws. As such, it is part of U.S. law. Its objectives, although not necessarily the instruments of reaching them, seem acceptable elsewhere, but again only if understood as a principle of conflict of laws committed to the domestic perspective of the foreign aspects of a case. Could such a principle be considered, as is claimed by the American Law Institute, to be part of international law?

The United States cannot expect its view of what is reasonable in a particular case necessarily to be shared by the foreign state concerned. On the contrary, that foreign State is likely to have a different view, or there would be no conflict of jurisdiction. From the perspective of that state, it could, for instance, make sense to permit, encourage, or even compel local industry to combine forces in order to penetrate the U.S. market. Such an export cartel, perfectly reasonable in the view of the foreign state, is an import cartel, from the perspective of the United States and liable to be prohibited there regardless of where it was formed and the nationality of its partners. That particular foreign State therefore disagrees as to the meaning of reasonableness, and so would the Untied States in the reverse situation when it assumes the role of promoting an export cartel. ${ }^{50}$ Yet, depending on market conditions, quite different attitudes could be adopted by the exporting and the importing state: The importing state could seek to protect domestic industry by urging foreign exporters to conclude a voluntary restraint

47. For a critical appraisal of comity, see F. Mann, Foreign Affairs in English Courts 134 (1986)

48. Montesquieu, XI De l'esprit des lois, ch. 6 (1748). II Oeuvres Completes 401 (1951).

49. For a recent discussion of the principle in general, with references to doctrine and court practice, see Vogel \& Martens, Gefahrenabwehr 389 passim (9th ed. 1986). For an example of its impact on limiting the scope of application of domestic law, see infra note 80 and accompanving text (Cigareltes case).

50. For example, see the point made by the United States companies in the Ilood Pulp case presently pending before the Court of Justice of the Furopean Communities, Ahlstrom Osakeyhtio v. EEC Comm'n, Joined Cases 89/85, Report for the Hearing $\S$ III.A.2., at 34 (to be incorporated into the judgment which is expected to be rendered by mid-1988). 
agreement, whereas those companies would at least sometimes expect greater benefits from lively competition among themselves, even in export markets.

In view of the diversity of interests under the parameters of time, place, and function, no chance exists to reach conclusions that reflect both international state practice and a high standard of reasonableness as determined by all the factors listed in section 403(2), not to mention the unlisted ones. Under such a multifactor analysis, the common denominator of the practice of the 160 or so states of the world will be established on a level at best reflecting a nondescript principle prohibiting an abuse of rights, which clearly falls short of the standard of administering justice in the particular case envisaged by the principle of reasonableness. As long as the world continues to be composed of more than one state, there will be no agreed understanding on what is reasonable in the meaning ascribed to that term in section 403(2). For the time being, the international law of jurisdiction establishes a mere minimum standard that sets outer limits within which national conflicts law may provide for optimum solutions from a domestic perspective. ${ }^{51}$

No way exists to accept the Restatement's claim for qualifying reasonableness as a rule of international law if the standard of reasonableness is interpreted by reference to an independent international law standard based on the common denominator of a widely diverging state practice. But that interpretation does not impose itself. Although the authors of the Restatement might have had a more ambitious goal in mind, it would be more in line with the general concept of reasonableness if the standard of reasonableness is understood to be referring back to domestic law by way of a renvoi: In order to delimit prescriptive jurisdiction, national law refers to international law which, under section 403(1) and (2), refers back to that same national law for the determination of what reasonableness means in a particular case.

The renvoi of reasonableness is to the enlightened self-interest of the state about to exercise its jurisdiction. An international law rule reflecting that interpretation of reasonableness could well be assumed to exist. The notion of restraint, as was said before, is generally shared though states differ on how to reach that aim. Such difference is entirely compatible with the idea of a renvoi to all the particularities of domestic law. States accommodate countervailing interests of foreign States to the extent that this seems reasonable from their own perspective, and they may be assumed to do so also at least on the ground of respecting foreign State sovereignty.

To be sure, an international law renvoi to enlightened self-interest adds no substance to the obligations already contained in the respective rules of

51. For an elaboration of the point by reference to the respective functions of international law and conflict of law, see Meessen, supra note 42, at 789-90, 801-02. See also Meessen, Kollisionsrecht als Bestandteil des allgemeinen Völkerrechts: Völkerrechtliches Minimum und kollisionsrechtliches Optimum, in International Law \& Economic Order 227 (W. Flume, H. Hahn, G. Kegel, K. Simmonds eds. 1977). 
national conflicts law. The value of such a rule of international law is exhortatory, but it also opens access to the remedies of the international law of state responsibility if the domestic law standard of reasonableness is not observed. This fact may explain the frequency of interventions of foreign governments trying to fend off such exercise of extraterritorial jurisdiction as is not even absolutely necessary to meet domestic interests. ${ }^{52}$

In this limited sense of states being obliged to follow their own enlightened self-interest, the principle of reasonableness can be deemed to qualify as a principle of customary international law. This writer suggests to go one step further; yet, the Restatement (Revised) stopped halfway, as will be discussed in the next subsection.

\section{Sovereign Equality of State Interests}

The original draft of subsection (3) of section 403 was still confined to paraphrasing reasonableness. An exercise of jurisdiction, not unreasonable as such, could nevertheless be unreasonable if it violated an exercise of jurisdiction which was not unreasonable in another state. Apparently, the reporters thought that reasonableness would suffice to handle any type of jurisdictional conflict. The full text of the first draft of section 403(3) read:

An exercise of jurisdiction which is not unreasonable according to the criteria indicated in Subsection (2) may nevertheless be unreasonable if it requires a person to take action that would violate a regulation of another state which is not unreasonable under those criteria. Preference between conflicting exercises of jurisdiction is determined by evaluating the respective interests of the regulating states in light of the factors listed in Subsection (2). 53

Then, in response to discussions with members and advisers of the Institute, a balancing of state interests, originally just one of many factors of reasonableness, received special emphasis. Section 403(3) was redrafted to read:

When more than one state has a reasonable basis for exercising jurisdiction over a person or activity, but the prescriptions by two or more states are in conflict, each state is expected to evaluate its own as well as the other state's interest in exercising jurisdiction in light of all the relevant factors, including those set out in Subsection (2); and to defer to the other state if that state's interest is clearly greater. ${ }^{54}$

Once more reacting to criticism from various factions, the ambiguity of "expected" conduct was resolved by splitting the rule into: (1) a strict obligation to undergo a process of balancing; and (2) a less strict obligation to

52. For the discussion of an example, see Meessen, The International Law on Taking Evidence From, Not In, a Foreign State: The Anschutz and Messerschmitt Opinions of the United States Court of Appeals for the Fifth Circuit, 25 InT'l. Legal Materials 832 (1986) (opinion, originally submitted to the United States Supreme Court in Anschutz and Messerschmitt, on withdrawing certiorari in Messerschmitt and granting certiorari in Aerospatiale, annexed to the Brief of Aug. 22, 1986, for Anschutz \& Co. and Messerschmitt-Bolkow-Blohm as Amici Curiae in Aerospatiale, 107 S. Ct. 2542 (1987).

53. Restatement (Revised) of Foreign Relations Law of the United States $\$ 403(3)$ (Tent. Draft No. 2, 1981).

54. Restatement (Revised) of Foreign Relations Law of the United States $\$ 403$ (3) (Tent. Draft No. 6, vol. 1, 1985) [hereinafter Draft No. 6]. 
defer to the "clearly greater interests" of a foreign State. The text of section $403(3)$, as it was formally adopted, provided:

When more than one state has a reasonable basis for exercising jurisdiction over a person or activity, but the prescriptions by two or more states are in conflict, each state has an obligation to evaluate its own as well as the other state's interest in exercising jurisdiction, in light of all the relevant factors, including those set out in Subsection (2), and should defer to the other state if that state's interest is clearly greater. ${ }^{55}$

The version about to be published, again, contains some alterations, which will remind readers of the very first draft. The beginning of the sentence was changed from the affirmative "reasonable" to the double negative "not unreasonable." Also, the words "including those set out in" were deleted. As a result, the reference to "Subsection (2)," which so far had given an example for "relevant factors" to be considered, is now couched as a citation to the entire procedural law obligation of balancing state interests and makes that rule look repetitive of what follows anyway from the principle of reasonableness. Finally, the unloved substantive law obligation of balancing state interests is no longer connected by "and," but is now split off by a semicolon to form its own sentence. In the version which is in the process of publication, section $403(3)$ reads:

When it would not be unreasonable for each of two States to exercise jurisdiction over a person or activity, but the prescriptions by the two States are in conflict, each State has an obligation to evaluate its own as well as the other state's interest in exercising jurisdiction, in light of all the relevant factors, Subsection (2); a State should defer to the other State if that state's interests is clearly greater. ${ }^{56}$

The comments to $\$ 403(3)$ also have their own history. With an unusual emphasis on the negative side, the reporters included a comment in Tentative Draft No. 6 which stated that "in the current state of international law, failure (to defer to the State with the greater interest) would not be considered a violation." 57 In 1986, in accordance with a suggestion made by this author in 1985, Douglas Rosenthal formally moved to delete that passage which had in the meantime been slightly changed. ${ }^{58}$ The amendment, with a modification suggested by Lloyd Cutler, was approved by a majority of 143 to 68 a day before the text of the entire Restatement was unanimously adopted. ${ }^{59}$ In their final version, the comments to section 403(3) neither deduct anything from, nor add to, the degree of binding force of "should defer" as stated in the rule itself.

The procedural law obligation to evaluate domestic and foreign State interests fully corresponds to the principle of sovereign equality of states. ${ }^{60}$

55. Restatement (Revised), supra note 1; identical with Restatement (Revised) of Foreign Relations Law of the United States \$ 403(3) (Tent. Draft No. 7, 1986) [hereinafter Draft No. 7].

56. Restatement (REvised), supra note 1, $\$ 403$ (Galley proofs as of Nov. 3, 1987, copies of which were kindly sent to the author by the American Law Institute.).

57. Draft No. 6, supra note 54, § 403 comment e.

58. Draft No. 7, supra note 55, $\$ 403$ comment e; 63 A.L.I. Proc. 95-97 (1987); 62 A.L.I. Proc. 429 (1986).

59. 63 A.L.I. Proc. 94-96, 106-07 (1987).

60. K. MeEssen, VölkerRechtLiche Grundsätze des internationalen KartellRechts 198 203 (1975); Meessen, supra note 42, at 804. 
Those in charge of applying domestic law are supposed to look at countervailing foreign interests as such, not just in the light of domestic foreign policy concerns. Indeed, it is for the foreign State to define its own position. Under its procedural aspect, therefore, the balancing rule reflects all those obligations to consult the foreign State concerned that are recommended by the Council of the Organization for Economic Cooperation and Development (OECD) and contained in a number of bilateral treaties and executive agreements. ${ }^{61}$

To determine whether balancing as a procedural rule forms part of today's customary international law, a large amount of diplomatic practice of discreet, early consultations will have to be collected and analyzed. In the field of antitrust law, for example, sufficient evidence exists to postulate the existence of such a rule. ${ }^{62}$ In fact, the rule was pleaded in International Business Machines Corp. v. Commission of the European Communities. ${ }^{63}$ In that case, the Commission initiated proceedings against IBM without having ascertained how the remedy of worldwide disclosure of technical data, which it threatened to impose, would be perceived by the United States, where IBM has its principal place of business. ${ }^{64}$ The Court of Justice of the European Communities reported the argument, and the Advocate General gave it some sympathetic attention. Nevertheless, IBM's complaint against the initiation of proceedings was declared inadmissible, and the issue was not reached. ${ }^{65}$

The more interesting and difficult question, of course, is whether states are obligated by substantive international law to defer to foreign States whose interests in the matter have more weight. As mentioned above, the Institute has remained short of a clearly affirmative response: A state "should" defer, but it does not have to do so. Again, where antitrust law is involved, this author postulated in 1975 that there is sufficient evidence for such an obligation in state practice. ${ }^{66}$ In 1984 , he reiterated that position and based it on additional evidence. ${ }^{67}$ In the form of a hypothesis, it may be extended to cover every field of law.

In explaining this position, it seems appropriate to remember the well chosen words of the late Judge Sir Gerald Fitzmaurice, by which he denied Spanish jurisdiction with respect to a certain aspect of the Barcelona Traction case, even though he joined the majority of the International Court of Justice in dismissing Belgium's complaint for lack of ius standi:

61. For the most recent version of the general OECD Recommendation, see Revised Recommendation of the Council Concerning Co-operation Between Member Countries on Restrictive Business Practices Affecting International Trade of May 21, 1986, 25 Inr'L Legal Materials 1629 (1986). For a collection of earlier OECD recommendations and of bilateral treaties, see A. LowE, Extraterritorial Jurisdiction: An Annotated Collection of Legal Materials 226-54 (1983).

62. K. MeEssen, Völkerrechtliche Grundsätze, supra note 60, at 229.

63. 1981 E. Comm. Ct. J. Rep. 2639.

64. Id. at 2648 .

65. Id. at 2659,2668 . On the merits, a settlement was later reached reflecting the substantive law part of the balancing rule. See Meessen, supra note 42, at 795 .

66. K. Meessen, Völkerrechtliche Grundsätze, supra note 60, at 231-32.

67. Meessen, supra note 42 , at 804 . 
It is true that, under present conditions, international law does not impose hard and fast rules on States delimiting spheres of national jurisdiction .... It does however... involve for every State an obligation to exercise moderation and restraint as to the extent of the jurisdiction assumed by its courts in cases having a foreign element, and to avoid undue encroachment on a jurisdiction more properly appertaining to, or more appropriately exercisable by, another State. ${ }^{68}$

To be sure, an obiter dictum, even from Sir Gerald, cannot by itself produce a rule of customary international law. However, this author is confident that an international tribunal, if ever charged with addressing the issue, will agree on the approach outlined in that passage. Strict territorial limitation does not work. Transterritorial conduct would otherwise often be outside the reach of any regulation. Frequent cases of concurrent jurisdiction must be accepted as a necessary element of economic interdependence. Yet sovereignty requires that the regulatory capacity of states be preserved even under conditions of overlapping jurisdiction. The various claims to jurisdiction, as rightly observed by Sir Gerald, must be compared, and the standard of comparison can only be that of sovereign equality, leaving each state with an equal chance to take effective legal action to implement its policies.

State practice of interest balancing extends well beyond judicial case law. In the past, assertions of jurisdiction were often withdrawn in response to diplomatic pressure exerted by the foreign State concerned. Thus, settlements were negotiated on the diplomatic level, at times later to be included in consent decrees formally terminating litigation. This type of precedent is unfamiliar to anyone practicing national law, but it is the stuff of which customary international law is made: Challenges by one state are met with a response from another state. If, as a result of such interaction, a uniform pattern of conduct develops and that conduct is related to principles of international law, then a rule of customary international law is likely to have come into being.

Those criticizing the balancing rule argue that it does not lend itself to application by national courts. ${ }^{69}$ Yet U.S. practice which, applying comity principles, usually focused on a balancing of domestic and foreign state interests offers considerable evidence to the contrary. The courts have not even, as may be suspected, always preferred U.S. interests. Among the recent examples, Aerospatiale is the most prominent. Even under the less international-minded majority view, the decision of the court below was vacated and the case remanded with more than a faint possibility of Convention procedures being pursued as the French government had requested. ${ }^{70}$ One district court, balancing state interests in the way suggested by the minority opinion in Aerospatiale, obliged plaintiff first to make use of

68. Barcelona Traction, Light \& Power Company case (Belgium v. Spain), 1970 I.C.J. 3, 105 (separate opinion of Judge Fitzmaurice).

69. See, e.g., Mann, The Doctrine of International Jurisdiction Revisited After Twenty Years, 186 ReCUEIL des Cours 9, 45, 52, 83, 89-90 (1984).

70. See Aerospatiale, 107 S. Ct. 2542, 2557 (1987). 
Convention procedures before a request for interrogatories could be granted. ${ }^{71}$ After Aerospatiale, two other courts refrained from ordering the production of documents located in a foreign State in view of the objections of the respective state and other elements of interest balancing. ${ }^{72}$

To be sure, municipal courts, comparing state interests under the balancing rule, must cope with some of the same problems as when applying the principle of reasonableness: There is no meaningful standard of reasonableness under international law; nor does international law provide a common standard for evaluating state interests under section 403(3). Nevertheless, such comparative analysis has a better chance of succeeding than measuring conduct under an absolute standard as undefined and untested as reasonableness is in international law. First, lawyers are used to the relativist reasoning of comparing interests of different categories. Second, objectivity often results from both states pursuing similar, however opposed, policy objectives since, in that case, the relative weight of the various interests involved can be measured by using traditional conflict of laws techniques, such as comparing the significance of the connecting factors to each of the states. Also, the dignity of state interests, more often than not, can be assessed by reference to pronouncements of law and policy by the respective state itself. These pronouncements sometimes support, and sometimes contradict, the position adopted by that state regarding the particular dispute and thus allow observers to draw conclusions without reference to any absolute standard of international law.

To limit respect of foreign interests to those expressed by foreign statutory regulation would be contrary to the principle of sovereign equality. That principle which allows all the factors listed in section 403(2) to be considered from the perspective of the regulating state correspondingly prohibits taking account of the interests of the foreign State only to the extent that they are incorporated in acts of legislation. Also, foreign States should not be encouraged to enact blocking legislation to protect "a strong policy" which, according to the Institute's comments, is unfortunately supposed to be excluded from consideration under section 403(3)..$^{73}$ In conformity with the position presented here, the Supreme Court refrained in Aerospatiale from relying on the presence of a French blocking statute for an assessment of countervailing interests of that state. ${ }^{74}$

Another problem faced by national courts relates to the need for involving the executive branch in a realistic appraisal of the various state interests. Above all, the executive branch must be induced to contact foreign governments unless this has already been done in compliance with the procedural part of the balancing rule. In view of applying both subsections

71. Hudson v. Hermann Pfauter \& Co., 117 F.R.D. 33 (N.D.N.Y. 1987).

72. In re Sealed Cases, 825 F.2d 494 (D.C. Cir. 1987); Minpeco v. Hunt, 116 F.R.D. 517 (S.D.N.Y. 1987).

73. Restatement (Revised), supra note $1, \S 403$ comment $e$.

74. See Aerospatiale, $107 \mathrm{~S}$. Ct. at 2556; cf. id. at 2562-64 (minority opinion). For an elaboration of the general point, see Meessen, supra note 42, at 806-07. 
(2) and (3) of section 403, adjustments of national procedural law may have to be considered to improve coordination between the judicial and executive branches of government without, however, politicizing what should remain a question of law.

In order to further strengthen the legal context, international arbitration should be made available to assist national courts. The author is pleased to note that his proposal to set up interlocutory procedures for referring jurisdictional cases to an international arbitral tribunal ${ }^{75}$ has received the endorsement of an eminent judge at a national court. Ruggero J. Aldisert, then Chief Judge of the United States Court of Appeals for the Third Circuit, agreed, with the proviso, however, that the international tribunal should only have advisory functions. ${ }^{76}$ Even with this limitation, arbitration could contribute to an unbiased handling of interest balancing by national courts.

Normally the executive branch of the government must be responsible for applying the balancing rule by carefully sounding out what the interests of the foreign State concerned are, assessing their relative weight, and working out compromise solutions with the foreign government. If, as in private litigation, the executive branch has no occasion for doing this, or if it fails to reach acceptable conclusions, courts will have to continue to step in, either by directly applying the balancing rule as part of higher-ranking international law or by indirectly avoiding an infringement through the use of domestic law devices such as comity. The American Law Institute correctly stated the procedural part of the balancing rule. If it remained short of attributing the character of strictly binding law to the substantive part of the balancing rule, at least it offered, for further discussion, a formulation of the rule.

\section{IV}

\section{False and True Conflicts of Jurisdiction}

Under section 403(1) and (2) of the Restatement, balancing of state interests is probably the most important element of reasonableness analysis. Under section $403(3)$, it also constitutes the contents of an international law rule to that effect to defer to greater interests of foreign States. The difference between those two functions of balancing state interests may perhaps be clarified by referring to a distinction made in the theory of governmental interest analysis between false and true conflicts. ${ }^{77}$ The reference, as may be pointed out, is to the terminology and not to any of the controversial propositions put forward by governmental interest analysis. ${ }^{78}$ The balancing rule, under neither of its two aspects discussed here, purports

75. Meessen, supra note 42, at 809-10.

76. Aldisert, Federal Courts and Extraterritorial Antitust Law: Enlightened Self Interest or Iankep Imperialism?, 5 J. L. \& Сом. 415, $430-31$ (1985)

77. For a terminological survey, see Westen, False Conflicts, 55 Calif. L. Rev. 74 (1967).

78. For a statement of the theory, see Currie, Notes on .Methods and Objectives in the Conflict of Lares, 1959 Duke L.J. 171. For a critical appraisal, see Juenger, Conflict of Law's: At Critique of Interest thalysis. 32 Ам. J. Coмp. L. 1 (1984). 
in any way to limit recourse to traditional techniques of conflict of laws. It offers itself as a last resort to be taken only after other methods of conflict avoidance and conflict resolution have failed.

False conflicts are here defined as conflicts of jurisdiction even though they are not. The paradox is dissolved by introducing the time element: State A asserts jurisdiction. State B objects. State A then finds, on a second look, that it can meet its regulatory interests without impairing State B's interests. Or, States A and B, each of them reevaluating its own interests, reach a compromise. What began as an antagonistic conflict was, in the first case, revealed to be a false conflict. In the second case, the conflict was turned into a false one by way of "mutual adjustment."79

The German part of the Cigarettes case, ${ }^{80}$ for the most part, was soon understood to constitute a false conflict situation. The German Federal Cartel Office ("FCO") decided to take up investigations regarding a foreign merger transaction linked to Germany solely via the German subsidiaries of each partner to the transaction. Britain complained, protesting against the FCO's intention to prohibit the South African Rembrandt Group from selling half of its shares of Rothmans Holdings, a British firm, to the U.S. corporation Philip Morris. In response to the British representations, the FCO made it clear that it would limit divestiture to the German subsidiaries by requiring, for example, the sale of one of the subsidiaries to a third company not yet present on the German cigarette market in order to preclude any adverse effects on competition in Germany. The British government agreed it was up to the Germans to take measures dealing with the German end of the transaction. The international conflict between Germany and Great Britain, unlike a controversy with South Africa in the same case, turned out to be a false conflict: The FCO adopted a prohibition order designed to preserve the structure of the German cigarette market without preventing the companies from consummating the main transaction; the Kammergericht, the Berlin court of appeal reviewing measures of the FCO, confirmed the order with a proviso further clarifying its territorial limitation.

Under the Restatement, conflicts of jurisdiction may be discovered as, or turned into, false conflicts by application of the principle of reasonableness. The enlightened domestic perspective demands the incorporation of foreign countervailing interests to the extent possible. In the United States, the limitation of the prohibition order in the Cigarettes case would have been required under the principles of comity and reasonableness. In Germany, it was required under the constitutional law principle of proportionality and its

79. For a sociological study of that process, see C. Lindblom, The Intelligence of Democracy, Decision Making Through Mutual adjustment (1965).

80. Decision of July 1, 1983, Kammergericht, Wirtschaft und Wettbewerb/ Entschideungssammlung OLG 3051 (on appeal to the Federal Supreme Court, declared moot by decision of Oct. 29, 1984, without further considerations of international law or conflict of laws, Bundesgerichtshof, Wirtschaft und Wettbwerb/Entscheidungssammlung BGH 2211 ). 
merger control off-spring, the so-called "in-so-far-as formula," 81 even though the court, paying respect to the many scholarly opinions submitted, unnecessarily referred to considerations of international law. In Aerospatiale and its aftermath, ${ }^{82}$ the reference to comity and reasonableness was based on domestic conflicts law and brought about results in conformity with both foreign and domestic interests.

Only in true conflict situations must international law step in directly. In those cases, the enlightened self-interest of State A suggests that it go ahead and assert jurisdiction even though the enlightened self-interest of State $B$ clearly suggests otherwise. True conflicts cannot be resolved by national conflicts law; that is, each state under its conflicts law decides them in favor of its own law. ${ }^{83}$ International law, however, resting upon the principle of equality of states, looks at the enlightened self-interest of both State A and State B.

In a true conflict of jurisdiction, State A of the foregoing example would, under section 403(3), be supposed to or, in the opinion of the author, be obliged to refrain from taking any measure whose negative effects in State B are likely to be greater than its positive effects in State A. In practice, it usually means that State A must look for a compromise solution reconciling domestic and foreign interests. But it may also mean that State A must refrain from taking any action at all. The termination of the Pipeline controversy may be seen to reflect that type of conflict resolution. ${ }^{84}$

The Pipeline controversy between the United States and several states of Western Europe reached its culmination when the United States was faced with open disobedience on the part of British, French, German, and Italian companies, strongly supported by their respective governments. Instead of further escalating sanctions until breaking point would be reached, the United States Government decided to reduce the black-listing to a limited set of goods and thereby signaled its intention of settling the dispute. ${ }^{85} \mathrm{~A}$ settlement was actually reached three months later when the United States Government suspended all measures with a merely vague prospect of improved transatlantic coordination of embargo policies in the future.

Was the sudden turn to moderation due to a reappraisal of domestic commercial and political interests? Or did it reflect deferral to superior European interests involved in the Pipeline dispute? The latter interests had only then been clearly stated, whereas U.S. business interests were known to be at risk all along, and the political situation in Poland had not at all changed

81. See supra note 49 and accompanying text. For an elaboration, see K. Meessen, KOLLISIONSRECHT DER ZUSAMMENSCHLUSSKONTROLLE 17-20, 85 (1984).

82. See supra note $36,71,72$.

83. See Currie, Married Women's Contracts: A Study in Conflict-of-Laws Method, 25 U. CHI. L. REv. 227, 259-60 (1958).

84. For a survey and for references to the various regulations, see Bockslaff, The Pipeline Affair of 1981/82: A Case Histon, 27 Ger. Y.B. INT'L L. 28 (1984).

85. That point, of critical importance to a proper understanding of the course of events, was mentioned in Thompson, United States Jurisdiction over Foreign Subsidianes: Corporate and International Law Aspects, 15 Law \& Pol. InT'L Bus. 319, 356 n.174 (1983). 
for the better. From a U.S. perspective, leaving aside the wisdom of the policy move as a whole, there was no good reason not to make use of the full range of sanctions at the disposal of the government. Rather, a sense of sovereign equality, and perhaps even a desire to comply with an international law principle to that effect, seems to have had a role to play, to be sure, along with belated considerations of foreign policy regarding close allies and friends.

In the author's view, balancing domestic and foreign interests was essential to the termination of the Pipeline controversy. Yet, the impact of international law can be more clearly established in disputes determined by the courts. In the absence of a precedent decided by an international tribunal, the Bayer/Firestone case may serve as an example. ${ }^{86}$

In that case, a German court vacated an order prohibiting a merger transaction, inter alia, because it was not in conformity with the international law balancing rule of non-interference. The merger, to take place in France between the French subsidiaries of a German and an American firm, was expected to have perceptible, though not abundant, anti-competitive effects in Germany and thereby to draw the application of German antitrust law. At the same time, however, the more important effects of the merger were deemed to arise in France where plants would have to be closed down, resulting in a loss of jobs unless the merger proceeded as planned. Paying respect to the greater interests of France could only be justified under the international law balancing rule. From the perspective of German competition law, no account could be taken of French interests of employment policy since, unlike the situation in the Cigarettes case ${ }^{87}$ a compromise by proceeding merely against the German end of the transaction was not possible.

The conflicts in Bayer/Firestone and in the Pipeline case did not develop into false ones. Yet even true conflicts of jurisdiction have to be resolved one way or another, through power or through law. A legal solution would have to be derived from law existing outside and prevailing over the domestic laws of both states: international law. The international law balancing rule is observed, therefore, not because states spontaneously find it to be within their interest to accommodate certain foreign interests, but because foreign protests induce them to abide by the rule even though the specific course of action prescribed by the rule may not lie in their interest at all. For once, a heteronomous rule of international law breaks into the realm of the autonomous rules of conflict of laws.

Under the balancing test that forms part of the principle of reasonableness, as laid down in section 403(1) and (2), conflicts of jurisdiction are, if possible, to be interpreted as, or turned into, false conflicts. In that respect, balancing the various state interests is tied into domestic conflict of laws calling for a multifactor analysis establishing the enlightened selfinterest. International law provides for an additional remedy but has nothing

86. Decisions of Nov. 26, 1980, Kammergericht, Wirschaft und Wettbewerb/ Entscheidungssammlung OLG 2411, 2419.

87. See supra note 80 and accompanying text. 
in substance to add. Reasonableness always has to be determined from the domestic perspective.

Balancing under section 403(3) deals with true conflicts of jurisdiction, that is, with conflicts of jurisdiction that cannot be solved with the instruments of domestic conflicts law, not even if based on a most enlightened understanding of domestic interests. As a genuine rule of international law, it is confined to a balancing of those interests that have a standing under international law, that is, to a balancing of state interests. The rule is to protect the sovereignty of foreign States, in time of frequent jurisdictional overlap, against unlawful interference. The balancing of the respective state interests, under the balancing rule of non-interference, is by no means openended. It is subject to the principle of equality of states which is at the very basis of international law. Although, in practice, it leaves some room for political decision-making, its message of equality as a guideline for the solution of true conflicts of jurisdiction should not be diluted. 
